\title{
USING FLASH CARDS TO IMPROVE STUDENTS' VOCABULARY
}

\author{
Aisyah Siti Khasanah Atmaja ${ }^{1}$, Gina Sonia ${ }^{2}$ \\ ${ }^{1}$ IKIP Siliwangi \\ ${ }^{2}$ IKIP Siliwangi \\ ${ }^{1}$ aisyahska502@gmail.com, ${ }^{2}$ soniagina99@gmail.com
}

\begin{abstract}
Vocabulary is one of an important thing in English learning. That is the reason why vocabulary is crucial in language learning. Teaching vocabulary using flashcard chosen as the theme of this classroom action research. The sample of this research was seven grade of junior high school in Katapang. The researcher presented the result and the analysis of data collected that consist of cycle 1 and cycle 2. Each cycle of the research consist of planning, acting, observing and reflecting activities. In the research, there are some steps before cycle 1 and cycle 2 , there are observation and pre-test. The last steps after cycle 1 and cycle 2 are post-test. In the pre-test the researcher used the convensional method. Most of students not active and enthusiasm in the lesson in cycle 1.But, when the researcher used flashcard, the student more active and interest. It could be seen in mean score of the post-test in cycle 1, that is 79.50 . After that, in th cycle 2 , the mean score was 87.50 . It was higher that pre-test. Finally, from the researcher explanation concluded based on the qualitative data that consist of pre-test until post-test, that flashcard could advance the students vocabulary
\end{abstract}

Keywords: Flashcard, Vocabulary, Classroom Action Research

\section{INTRODUCTION}

English is a foreign language which is directed in schools, from elementary school to college level. English is an international language used to communicate with others in the world. Student have to know that they use English when they communicate with others in another wold.The vocabulary is one of the basic competence in learning English. The teacher and student will get the same think by using appropriate and correct vocabulary.

According to Prozesky (2000), learning is learn informally from what we experience day by day: things which happen to us make us change the way we think and act.. It is due to the fact Thar both of them are essential in accepting new knowledge for the students. Without teaching, learning process cannot be evaluated well. Moreover, without learning, the students cannot enhance their capability in mastering new knowledge.

According Hatch and Brown (1995) cited by Lestari (2015), vocabulary is a list or set of words for a particular language or a list or set of words that individual speakers of language might use. It means that vocabulary is the basic language aspect that must be mastered before mastering English skill.

A flashcards is part of a set of cards on which are written items to be studied. Based on these problems, researchers determined to apply flashcards as learning media. According to Cross (1991), flashcards is a simple picture on the piece of card or paper, and usually this media always used as a education tools. 
The student in seventh grade junior high school begin to learning English. They begin to know and mastery many simple vocabulary, start from nouns, verbs and adjectives. The knowledge of seventh grade students in one of school in Katapang on English vocabulary tends to be minimal. It is because of students lack of experience and motivation. The students experiencein learning English is less, because many children are weird in learning English. They have never studied English in elementary school. It causes their English vocabulary less. The second cause is the lack of learning motivation. This is because they do not figure out English. So they are lazy to enhance their knowledge of English.

One of the purposes of teaching English using flashcard is to enhance students vocabulary mastery. A flashcards contains a word and a number of user generated feature such as definition, example sentence, and pronunciation clips. Students view a card's content to study a word. Occupying on the problem mentioned above, the problem of the research is : how does flash card develop the vocabulary to the seventh grade student inKatapang.

The design of the study is to define how flash card develop the vocabulary to the seventh grade students in Katapang. The benefits expected from the study include the following : (1) to provide additional knowledge to other education researches dealing vocabulary, (2) to provide additional information to students to encounter the most suitable methods to develop their vocabulary, (3) to give additional information to student and teacher about the effectiveness of flashcards to improve students' vocabulary.

\section{METHOD}

This research conducted on students in seventh grade of second semester at Junior High school in Katapang. In this research, the researcher choose the second semester because students already know about English vocabulary. In addition, students also have started to read and string words into sentences.

This research used Classroom Action Research. As stated by Gregory, Kemmis and McTaggart (in Richard, 2000:12), as cited by Argawati, \& Syahrizal, (2016) action research is used to refer to teacher-initiated classroom investigation which seek to increase the teacher's understanding of classroom teaching and learning, and to bring about change in classroom practices.

Ferrance (2000) explain that typically, action research is undertaken in a school setting. It is a reflective process that grant for inquiry and discussion as components of the "research." Often, action research is a collaborative activity among colleagues searching for solutions to everyday, real problems experienced in schools, or looking for ways to enhance instruction an increase student achievement.

According to (Kemmis and Taggart, 1988) basic component to design Class Action Research, there are four steps, namely : planning, acting, observing and reflecting in one cycle. In a research, a researcher may have more than one or two cycle depends on how difficult the problem the writers face. Each cycle is followed by another cycle where the previews cycle is used as a basis of deciding what should be done in the next cycle.

The researcher collected quantitative and qualitative data. Quantitative data view from the skill of student in mastering vocabulary by doing two test, that is pre-test and post-test. In this case, students score is analyzed by searching the mean score in every test, from pre-test, post-test 1 and post test 2. The mean score for each test is compared to find out the advance of 
students'capability in understanding English vocabulary. Therefore, with qualitative data the ability of students can be more attention.

Test results can explanation the problem of whether the application of flashcards could improve students' vocabulary. This can be identified from the mean differences in pretest and posttest. According to Ngadiso (2013: 5-7, cited in Parmawati, A., \& Yugafiati, 2017), the mean of the pretest and posttest could be computed using the following formula:

$$
\begin{aligned}
& M=\sum x \\
& N
\end{aligned}
$$

In which

$\mathrm{M}=$ Mean score

$\sum x=$ Total score

$\overline{\mathrm{N}}=$ Total students

If all of the students give good responses to the teaching-learning process and their posttest score is higher than pretest score, the method is successful. On the adverse, if the students not, the technique is unsuccessful. In Analyzing the data, the researchers integrated and related the findings to background of the study, mainly to the research questions, theories, and the methodology for classifying the data into manageable units as suggested by Emilia (2008:201, cited in Apsari, 2018)

\section{RESULTS AND DISCUSSION}

\section{Results}

The researcher will discusses about the result of research and describes about the conducted of teaching to improving the vocabulary mastery using flashcard and to know the effectiveness of using flashcard to facilitate teaching vocabulary to student. The researcher presented the result and the analysis of data collected that consist of cycle 1 and cycle 2. Each cycle of the research consist of planning, action, observation and reflection activities. In the research, there are some steps before cycle 1 and cycle 2, there are observation and pre-test. The last steps after cycle 1 and cycle 2 are post-test. The conducted of the research is start from 3 September 2018 for pretest, 6 September for cycle 1, and 10 September 2018 for cycle 2. Actually, there are twenty (20) student that follow the pre-test. This is the result of all cycles are as follows :

\section{a) Analysis of Pre-test}

At this time, the student learning about descriptive text, so the researcher decided to give vocabulary based on what they have learned at that time. From the observation result the student have not know well about the vocabulary in descriptive text. When they did the test, some of them inquire the teacher about the meaning of the words given. In this step, the researcher gave the pre-test to student without flashcard. There are 15 questions which consist of 10 vocabulary list and 5 fill the blank. After the test, the researcher gave the score. Each correct answer was scored 1 and 0 to each false answer. The result for the pre-test is below :

The computation of the average of the score was as follows :

$$
\text { Average }=\frac{1150}{20}=57.50
$$


It demonstrate that the mean score of the students in pre-test was 57.50 . however, KKM ( Kriteria Ketuntasan Minimum) or the criteria English passing grade is 75.00. It means that the student could be categorized as poor and their vocabulary was very low.

The researcher kept the answer and said to the student that next meeting would have explaination about the purpose of pre-test. In this case, the researcher concluded that the treatment in each cycle were necessary to improve the students result.

\section{b) Analyis Cycle 1}

After doing the pre-test, the researcher continued to the next step, that is cycle 1 . In cycle 1 , there was four steps, namely : planning, acting, observing and reflecting.

1) Planning

Based one the problem in pre-test, the researcher planned to used flashcard in teaching vocabulary to improve their vocabulary mastery.In a planning, the teacher prepared the material to support learning and teaching activities such as flashcards as a main media, picture and also students worksheets.

2) Acting

In this stage, the researcher acted as a teacher. The teacher told themthat during the lesson they had to listen carefully. Moreover, the teacher command them to be quiet and do not make a noisy in the class. When the teacher began the lesson, the students were easy to be handle and gave more attention to the teacher. The teacher began the lesson with explaining about some verbs in the class activities. Then, the student were given some vocabulary list which was used in the previous pre-test. The teacher asked them to finding the meaning of the words in Indonesia and also in English by using the dictionary. After they are finding the meaning of the words, the teacher asked to them and the teacher started to explain this vocabulary with flashcards. After the teacher explain the vocabulary, the teacher asked the students to repeat the words correctly. Then, the teacher showed the flashcards randomly and the students answer correctly.

The next activity, the teacher gave the students a worksheets consist of 10 picture about class activies. The teacher asked them to write the answer in the worksheets with Indonesia and English. After finished, the teacher collected and checked the students answer.

3) Observing

The observation was held during the learning process. It was done to identify the implementation of flashcards to improve students' vocabulary. In this cycle, the techniques that teacher used were explaining, showing, repeating and individual test. While the teacher gave the students an individual worksheets to finding and matching the words with picture, the students did the worksheets with high concentration and enjoy the process.

4) Reflecting

Based on the observation and test in the first cycle, the researcher found some improvements and problems.

a. Improvements

The students were enthusiastic in learning activity. They also enjoyed the learning process. Moreover, they knew the new words. Besides that, there was an 
improvement in students' vocabulary value. It is can be seen from the students pretest and post-test in the cycle 1 . The mean score of pre-test were 57.50 and the mean score of post-test were 79.50.

b. Problems

The students' word-spelling ability was still small. It can be seen from the result of their worksheets.

In general, there were improvement on srudents' vocabulary, but they had a problem in writing the vocabulary and some students not acive in learning process. So, the researcher need to solved the problrm in cycle 2 .

\section{d) Analysis of Cycle 2}

After implementing cycle 1, the teacher continued the learning process to next cycle.In this cycle, the researcher planned to solved the problem before. This stage was same as the cycle 1 , there are planning, acting, observing and reflecting.

1) Planning

From the first cycle, there were two main problem. The first about students' spelling ability and the second about students' participation. This problem could be solved by group discussion and flashcards game. In this cycle, students would given 10 new words. Then, the 10 new words combined with the previous words. In the end, the researcher gave a post-test to measure students' vocabulary improvements.

2) Acting

This step was held on 90 minutes. The learning process started with pray together, greeting and checked an attendance list. Next, the teacher review about the previous lesson. Before using the flashcard, The teacherdemand the student to make a group, consist of five students. After that, the teacher gave every groups some flashcard and they should finding the meaning of the words both in Indonesia and English using the dictionary. Next, the teacher demand them to describe a picture in a flashcards, the time for discussed was 30 minutes.

After the discussion, the teacherasked the students to share what the picture they get to other group. Totally, there were 10 new words, then the 10 new words combined with the previous words. Thetaecher also explain how to spelling and writing the correct words.

After give 10 new words and explain the words with flashcards, the teacher give the test to the students. The test is about the 25 words in the flashcards. The students should answer the vocabulary list with correctly. That are 10 question to fill in the blank and 15 question to find the meaning of the words. In the closing activity, the teacher asked student to learn more about the new vocabulary.

3) Observing

In cycle two, students' enthusiast more increase than before. The students enjoy the learning activity, because they know about the new words and they can describe the picture in the flashcard. They paid more attention and answered the teacher's questions. Moreover, the situation in the cycle 2 could be controlled and enjoy than before.

4) Reflecting 
Based on the observation and the test, the researcher can determine that the vocabulary mastery of the student was increase. Most of the student can answer the question correctly.The student's vocabulary scores were increase. It could be seen from the post test in the cycle one, that means was 79.50and in the cycle two the students scores to be87.50. Based on the analysis, it could be seen that the student can improve their score. It told that flashcards could improve the student's vocabulary. It was proved by the result of the student's score were higher than before.

\section{Discussion}

After analyzing the research result form the document, test and the observation, the researcher got finding that the student's vocabulary can improve by flashcards and the significant refinement of student's vocabulary mastery.The result of the pretest, posttest $n$ cycle 1 and posttest in cycle 2 showed the improvement of the students vocabulary mastery. The improvement could be seen from the increase of the mean student's vocabulary scores. The mean score summarixed in the table below :

Table 1. Table of the Finding Result

\begin{tabular}{cccc}
\hline KIND OF TEST & Pre-Test & $\begin{array}{c}\text { Post Test } \\
\text { Cycle 1 }\end{array}$ & $\begin{array}{c}\text { Post Test } \\
\text { Cycle 2 }\end{array}$ \\
\hline Total Score & $\mathbf{1 1 5 0}$ & $\mathbf{1 5 9 0}$ & $\mathbf{1 7 5 0}$ \\
\hline Mean Score & $\mathbf{5 7 . 5 0}$ & $\mathbf{7 9 . 5 0}$ & $\mathbf{8 7 . 5 0}$ \\
\hline $\begin{array}{c}\text { Increase Of The } \\
\text { Students Mean Score }\end{array}$ & - & 22.00 & 8.00 \\
\hline
\end{tabular}

As whole meetings have run well, there was some significant improvement from cycle 1 and cycle 2 . In the pre-test, the researcher use the conventional method because not used the flashcards. Most of student not active and enthusiast in the lesson.. in the cycle 1, the researcher use the flashcards and the student more active and interest. It could be seen in mean score of the post test in the cycle 1, that is 79.50. After that, in the cycle 2, the mean score was 87.50. It was higher than the pre-test. The teaching learning process in the cycle 1 and the cycle 2 was used the same steps, that is planning, action, observation and reflection. Most of the student also gave their high attention to the learning process. All activity in this cycle run well. It could be terminate that there was some improvement from the pre-test until the last post test.

Finally, from the explanation the researcher concluded based on the qualitative data that consist of pre-test until post test, that flashcards could improve the student's vocabulary. It was proven by the increase of the student's score. The students were happy and enjoy the learning process with using flashcards. The flashcards very helpful to improve the student's vocabulary. Therefore, this research of the improvement the student's vocabulary using flashcards was successful.

\section{CONCLUSION}

As a result of conducting this research, the researcher propose that the aim of the study is to describe how flash card improve the vocabulary to the seventh grade student in Katapang on the academic year 2017-2018. The benefits expected from the study include the following : (1) to provide additional knowledge to other education researches dealing vocabulary, (2) to provide additional information to students to find the most suitable methods to improve their 
vocabulary, (3) to give additional information to student and teacher about the effectiveness of flashcards to improve student's vocabulary.

\section{ACKNOWLEDGMENTS}

1. Alhamdulillahirabbil'alamin,the researcher expresses her highest gratitude to Allahsubhanahu wa ta'ala for blessing, love, opportunity, health, and mercy to complete this jurnal.

2. I am deeply thank to my lecturer, Mr. Tris and Mrs Irma for warm support, inspirational and thoughtful guidance.

3. I am enormously grateful to my beloved Mom for his continuous encouragement, kindly advice throughout my study.

4. I am thankful to my bestfriend, Mrs Dian Farida and Mrs Sari Sadiah for kind advice and help you give.

\section{REFERENCES}

Apsari, Y. (2017). The Use Of Picture Series In Teaching Writing Recount. ELTIN JOURNAL, Journal Of English Language Teaching In Indonesia, 5(2), 51-56.

Argawati, N. O., \& Syahrizal, T. (2016). The Use Of Task-Based Instruction To Improve Speaking Skill To The Second Semester Students Of STKIP Siliwangi Bandung On The Academic Year Of 2014-2015. P2M STKIP Siliwangi, 3(1), 1-8.

Cross, D. (1991). A Practical Handbook Of Language Teaching. London: Cassel.

Ferrance, E. (2000). Themes In Education: Action Research. Brown University: Educational Alliance, 34(1).

Lestari, A. N. (2015). The Effectiveness Of Using Hangaroo Game For Teaching Vocabulary (An Experimental Research At Seventh Grade Students Of SMP Negeri 3 Sokaraja In Academic Year 2014/2015)(Doctoral Dissertation, Universitas Muhammadiyah Purwokerto).

Kemmis, S. And Mactaggart, R. (1988). The Action Research Reader. Third Edition. Victoria: Deakin University Press

Parmawati, A., \& Yugafiati, R. (2017). Using Authentic Material To Improve Students'reading Interest (A Classroom Action Research In The Second Semester Students Of Stkip Siliwangi Bandung). Eltin Journal, Journal Of English Language Teaching In Indonesia, $5(1), 1-8$.

Prozesky, D. R. (2000). Teaching And Learning. Community Eye Health, 13(36), 60. 